\title{
The Role of Narcissism and Competitive Worldview in Predicting Environmental Apathy
}

\author{
Juneman Abraham a , Murty Magda Pane ${ }^{b}$ \\ a Psychology Department, Faculty of Humanities, \\ ${ }^{b}$ Character Building Development Center, \\ Bina Nusantara University, Jakarta, 11480, Indonesia \\ juneman@binus.ac.id
}

\begin{abstract}
In this study, hypothetical model included personality variables and social psychological variables by employing narcissism and competitive worldview as predictors towards apathy about environmental issues. The study was conducted on 225 college students (138 males, 87 females; Mage $=18.25$ years, $\mathrm{SD}_{\text {age }}=2.13$ years) taken through convenience accidental sampling technique from several majors of a private university in Jakarta, Indonesia. The results of path analysis showed that narcissism was able to predict apathy towards the environment indirectly through a competitive view of the world $\left(X^{2}=0.11, p=0.736\right.$, RMSEA $\left.=0.000\right)$.
\end{abstract}

Keywords: Environmental apathy; competitive worldview; narcissism; psychology

eISSN: 2398-4279 @ 2016. Authors. Published for AMER ABRA by e-International Publishing House, Ltd., UK.. This is an open access article under the CC BY-NC-ND license (http://creativecommons.org/licenses/by-ncnd/4.0/). Peer-review under responsibility of AMER (Association of Malaysian Environment-Behaviour Researchers), ABRA (Association of Behavioural Researchers on Asians) and CE-Bs (Centre for EnvironmentBehaviour Studies), Faculty of Architecture, Planning \& Surveying, Universiti Teknologi MARA, Malaysia. https://doi.org/10.21834/ajqol.v1i1.33 


\subsection{Introduction}

Indifference or apathy can be as destructive as anti-environmental attitudes. General apathy toward environmental issues is "a lack of interest in environmental issues, and a general belief that problems in this area have been exaggerated" (Thompson \& Barton, 1994, p. 151). This research assumes that environmental apathy is influenced by worldview. Worldview is "a set of assumptions about physical and social reality that may have powerful effects on cognition and behavior.... [Worldview] is a way of describing the universe and life within it, both in terms of what is and what ought to be" (Koltko-Rivera, 2004, p. 3, 4).

Worldview chosen to be a predictor of environmental apathy in this present study is 'competitive jungle worldview' as theorized by Duckitt and Sibley (2010). Competitive-jungle worldview is a social worldview believing "the world is a ruthlessly competitive jungle in which might is right, the strong win, and the weak lose as opposed to a place of cooperative harmony, in which people care for, help, and share with each other" (Duckitt \& Sibley, 2010, p. 1869). Evolutionary claim as proposed by Griskevicius, Cantú, and van Vugt (2012) that environmental apathy is rooted in human evolution needs further empirical test. This research proposes that one of the proxies of the evolutionary human development is worldview. Related to that matter, Duckitt's concept about competitive-jungle worldview contained a view "the social world is a competitive jungle characterized by a ruthless and amoral Darwinian struggle for survival, for resources and power" (Duckitt, 2001, p. 51; Duckitt, Wagner, du Plessis, \& Birum, 2002, p. 77). Thus, worldview chosen in this research is in line with evolutionary paradigm, which is proposed by Darwin. People who are high in the competitive-jungle worldview score will be low in the agreeableness personality scale (sympathetic, compassionate, and forgiving); in contrary they will be high in the scores of tough-minded, hard-hearted, and uncaring (Duckitt \& Sibley, 2010). They do not have empathy in chasing power and their individual purposes. Considering that cooperative action in the social dilemma situation (including environmental problems) will be higher for empathetic people (Rumble, Van Lange, \& Parks, 2010), this research assumes that there is positive predictive correlation between competitive-jungle worldview and apathetic toward the environment.

This research also presumes that competitive-jungle worldview is influenced by one's narcissism. Grafeman (2009) found that the individuals who show themselves through selfreport questionnaires as being high in narcissism-related traits are perceived by their peers as being competitive, hostile, and having a great willingness to control others. The psychological mechanisms underlying hypothesis about the predictive correlation between narcissism and competitive-jungle worldview can also be described by an analysis by Bushman and Baumeister (1998) which stated that narcissism is characterized by the feelings of superiority toward others; so that the neglect done by a narcissist toward other's rights and feelings can produce higher aggression. The narcissist perceives the social life as a series of struggles for dominance, thus they can attack others even though there is no direct threats. They carry out the attack only as a means to put them in a superior position 
by conquering or intimidating others. By integrating all of the propositions above, this research hypothesize that competitive-jungle worldview is a mediator of predictive relations between narcissism and environmental apathy.

\subsection{Methodology}

\subsection{Participants and design}

The participants of this research are 225 students (138 males, 87 females; Mage $=18.25$ years old, $S D_{\text {age }}=2.13$ years old) who are citizens of Jakarta, the capital city of Indonesia. The participants are recruited by using convenience accidental sampling technique from several majors of a university in Jakarta. Self-report questionnaires are distributed to classes which are attended by students from various study programs. The educational background composition of the participants of this research includes the following: Economics (Accounting, Management) 88 persons, Computer Science 74 persons, Visual Communication Design 41 persons, International Relations 10 persons, and others (Communication, Psychology, etc.) 12 persons.

The design of this research is a predictive correlational design. The data of this research is analyzed using path analysis done with the assistance of LISREL 8.8 program. Path analysis is an analytical method which is employed to see the relation of three or more variables (Seniati, 2009).

The predictor variable in this research is narcissism. The mediator variable is competitive-jungle worldview. The criterion variable is environmental apathy. According to Seniati (2009), the criteria to determine whether the model fit or not (the suitability between research model or measurement model with empirical data) are (1) Chi-square: Chi-square is valid if the normality assumption fulfilled and the size of the sample is large; The model is fit if $p>0.05$; (2) Goodness of Fit Indices (GFI): The model is fit if GFI > 0.90; (3) Root Mean Square Error of Approximation (RMSEA): The model is fit if RMSEA $<0.05$.

\subsection{Materials and procedures}

The participants were given psychological scales in Indonesian, which consist of three segments, to measure the predictor, mediator, and criterion variables. The scales were presented with six response choices, ranging from "Strongly Disagree" (scored 1) to "Strongly Agree" (scored 6). Preliminary items tryout, evaluation of the scales for their validity and reliability, as well as deletion of the invalid items were conducted in advance. Tryout (instrument testing) data were obtained from 55 students ( 31 males, 24 females).

The psychological scale for measuring environmental apathy is adapted from Thompson and Barton (1994). This scale consists of 9 items. The examples of these items are as follows: (1) "Environmental threats such as deforestation and ozone depletion have been exaggerated"; (2) "I do not feel that humans are dependent on nature to survive"; (3) "I 
do not care about environmental problems". The analysis of reliability and validity shows indices of Cronbach's Alpha 0.731 and corrected item-total correlations ranging from 0.282 to 0.637 , by deleting 3 items.

Psychological scale which is used to measure competitive-jungle worldview is adapted from Duckitt (2001). This scale consists of 14 items. The examples of these items are as follows: (1) "Winning is not the first thing; it is the only thing"; (2) "If it is necessary to be cold blooded and vengeful to reach one's goals, then one should do it"; (3) "It's a dog-eatdog world where you have to be ruthless at times". The analysis of reliability and validity show indices of Cronbach's Alpha 0.768 and corrected item-total correlations ranging from 0.300 to 0.617 , by deleting 7 items.

Psychological scale employed to measure narcissism is adapted from Pincus et al. (2009). This scale consists of 52 items. The examples of these items are as follows: (1) "It's hard to feel good about myself unless I know other people admire me", (2) "I often find myself envying others' accomplishments" (Contingent Self-Esteem); (3) "I find it easy to manipulate people" (Exploitative); (4) "I feel valuable when others rely on me" (SelfSacrificing Self-Enhancement); (5) "I often hide my needs for fear that others will see me as needy and dependent" (Hiding the Self); (6) "I often fantasize about accomplishing things that are probably beyond my means" (Grandiose Fantasy); (7) "Sometimes I avoid people because I'm afraid they will not do what I want them to" (Devaluing); and (8) "I typically get seriously angry when I'm unable to get what I want from others" (Entitlement Rage). The analysis of reliability and validity shows indices of Cronbach's Alpha 0.928 and corrected item-total correlations ranging from 0.272 to 0.752 , by deleting 3 items.

\subsection{Results and Discussions}

Path analysis shows that narcissism is able, indirectly, to predict environmental apathy through a competitive worldview (Figure $1 ; X^{2}=0.11, p=0.736, R M S E A=0.000$ ). The more narcissistic a person is the more the person sees the world as being full of competition, and as a result, the more the person does not care about the environment.

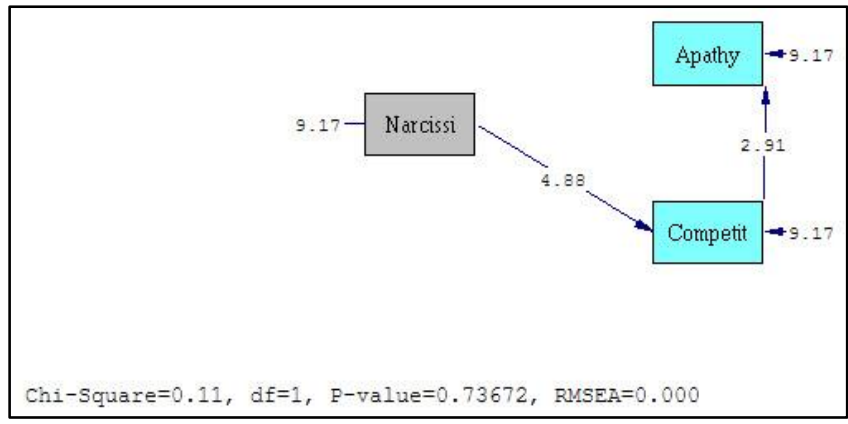

Figure 1: The result of path analysis $(G F I=1.00 ; T>1.96)$ 
Structural equations derived from the model are as follow:

Apathy $=0.28 *$ Competitive, Errorvar. $=34.10, \mathrm{R}^{2}=0.048$

$(0.097)$

2.91

9.17

Competitive $=0.081 *$ Narcissism, Errorvar. $=18.99, \mathrm{R}^{2}=0.12$

$(0.017)$

4.88
(2.07)

9.17

Observed from the coefficient of determination $\left(R^{2}\right), 4.8 \%$ of environmental apathy is contributed by competitive-jungle worldview, and $12 \%$ of competitive-jungle worldview is contributed by narcissism.

To our knowledge, this is the first research which found out that narcissism predicts environmental apathy through competitive-jungle worldview. The finding that competitive-jungle worldview can predict environmental apathy is in line with Hine et al.'s (2009) literature review. They found out that, in the common dilemma situation, competitive individuals or pro self-oriented, rather than cooperative individuals or prosocial-oriented, tend to overharvest jointly managed resources. In their empirical research, they found out that competitive individuals monitor the resources extraction that others do. The purpose is not to maximize collective outcomes, but to maximize personal benefit. Through the mechanism of upward social comparison, competitive individual increase resource extraction to make it more than their competitors, or maximize his own result (payoffs) before other people extract the resources. They also found out that individual with high score in the environmental apathy scale increases resources extraction after receiving feedback that other people also extract substantial resources.

Theoretical contribution of this present research is the inclusion of narcissism as a predictor variable. This research confirms recent findings of Luchner, Houston, Walker, and Houston (2011) that stated there is a relation between normal or non-clinical narcissism and competitiveness. Moreover, overt narcissism (e.g. grandiose narcissism) and covert narcissism (e.g. vulnerable narcissism) correlate positively with hyper-competitiveness, and overt narcissism correlate positively with general competitiveness. The results of this empirical study rebut Seth Robbins' (as cited in Singer, 2009) speculation arguing "Narcissism can help people believe that they have the power to solve large, complex problems such as climate change." This present research found out narcissism firstly influences competitiveness (competitive-jungle worldview), before influences environmental 
attitude (apathy). However, different from Robbins statement; the influence of narcissism is not constructive toward environment.

This research also confirms the finding of Twenge, Campbell, and Freeman (2012):

"Millennials reported thinking about social problems fewer, having less interest in government, making less effort to conserve energy, and being less interested in taking 'green' actions to protect the environment, either personally or through government."

Millennials meant by the researchers are people born after 1982. The participants of this current research are categorized as Millenials. However, this research gives new insight concerning psychological mechanism of narcissistic people in behaving toward the environment. This research succeeds to prove empirically that competitive worldview is responsible as a mediator of the relationship between narcissism and environmental apathy. It is understandable since narcissistic people have self-absorption tendencies and exploitative characteristics. For them environments are instruments functioning to gratify self-interest. The proliferation of narcissism and competitive worldview in the Millennials community cannot be separated from the role of mass media, which by various contests and reality shows provides a spotlighted stages and podiums.

In relation to the matter, it is necessary to examine the findings of Asmuni, Khalili, and Zain (2012). They found out that university students with a rural background show behavior scale of environment conservation (turn off unused electricity and purchase of energy saving appliances, turn off unused taps, use of designated recycle bins and some reuse activities) which is higher than students with urban background. Considering that this research is conducted toward students in the capital city of Indonesia, the findings of this research all at once can a little bit explain Asmuni, Khalili, and Zain researches.

Narcissism and the competitive worldview might not grow in the rural area; this condition is in contrary with urban area such as Jakarta. This explanation is in line with the finding of Cai, Kwan, and Sedikides (2012) recently which defines that urban persons are more narcissistic than rural persons. However, another crucial thing is that values and the worldview from a rural area can affect environmental conservation behavior in the future. Inspired by the findings, the intervention which can be proposed to overcome environmental apathy related to the view of the world is the finding of authentic identity (Piliang, 2010, p. 422). We have to escape from the 'identity trap or jeopardy' socially constructed within the discourse of consumerism and popular culture which is not authentic, dependent upon the imagination, fantasies, and illusions provided by the elite of cultural producer.

\subsection{Conclusion and Recommendation}

The assumption of the hypothesis supported by this study is that chronic admiration on the self and attitude of 'selfishness' in Darwinian terms made people competitive and lose the capacity to pay attention to the environment.

The findings of this current research imply that if we want to reduce apathetic among youths toward the environmental issues, we need to be attentive, to provide immediate 
treatment to their narcissism, and manage their worldview. Various professions, such as social psychologists, psychiatrists, clinical psychologists, school counselors, media experts, and environmental scholars can optimize their roles in helping youths to realize the psychological facts to prevent apathetic attitudes toward the environmental issues. The book edited by Barry, Kerig, Stellwagen, and Barry (2011) may add the understanding of how narcissism is formed and how to conduct an assessment to recognize it on the stages

of early development; so that preliminary intervention can be done. Further research may extend the thesis of this research by finding psychological or sociological variables that can be mediator or moderator candidates between variable of competitive worldview and variable of environmental apathy. The researches on the role of social influence from online social networks (Twitter, Facebook) in the relationship among variables which are examined in this research are also worth considering doing.

\section{References}

Asmuni, S., Khalili, J. M., \& Zain, Z. M. (2012). Sustainable consumption practices of University Students in Selangor, Malaysia. Journal of Asian Behavioural Studies, 2(6), 73-82.

Barry, C. T., Kerig, P. K., Stellwagen, K. K., \& Barry, T. D. (Eds.). (2011). Narcissism and Machiavellianism in youth: Implications for the development of adaptive and maladaptive behavior. Washington, DC, US: American Psychological Association.

Bushman, B. J., \& Baumeister, R. F. (1998). Threatened egotism, narcissism, self-esteem, and direct and displaced aggression. Does self-love or self-hate lead to violence? Journal of Personality and Social Psychology, 75(1), 219-229

Cai, H., Kwan, V. S. Y., \& Sedikides, C. (2012). A sociocultural approach to narcissism: The case of modern China. European Journal of Personality, 26(5), 529-535

Duckitt, J. (2001). A dual-process cognitive-motivational theory of ideology and prejudice. In M.P. Zanna (Ed.), Advances in experimental social psychology, 33, 41 -113. San Diego: Academic Press.

Duckitt, J., \& Sibley, C. G. (2010). Personality, ideology, prejudice, and politics: A dual-process motivational model. Journal of Personality, 78(6), 1861-1893

Duckitt, J., Wagner, C., du Plessis, I., \& Birum, I. (2002). The psychological bases of ideology and prejudice: Testing a dual process model. Journal of Personality and Social Psychology, 83(1), 75-93

Grafeman, S. J. (2009). Interpersonal perception of narcissism in an at-risk adolescent sample: A social relations analysis. Unpublished PhD dissertation, Graduate School of The University of Southern Mississippi.

Griskevicius, V., Cantú, S. M., \& van Vugt, M. (2012). The evolutionary bases for sustainable behavior: Implications for marketing, policy, and social entrepreneurship. Journal of Public Policy \& Marketing, 31(1), 115128 
Hine, D. W., Gifford, R., Heath, Y., Cooksey, R., \& Quain, P. (2009). A cue utilization approach for investigating harvest decisions in commons dilemmas. Journal of Applied Social Psychology, 39(3), 564-588.

Koltko-Rivera, M. E. (2004). The psychology of worldviews. Review of General Psychology, 8(1), 3-58

Luchner, A. F., Houston, J. M., Walker, C., \& Houston, M. A. (2011). Exploring the relationship between two forms of narcissism and competitiveness. Personality and Individual Differences, 51, 779-782

Piliang, Y. A. (2010). Dunia yang dilipat: Tamasya melampaui batas-batas kebudayaan (3rd ed.). Bandung: Matahari.

Pincus, A. L., Ansell, E. B., Pimentel, C. A., Cain, N. M., Wright, G. C., \& Levy, K. N. (2009). Initial construction and validation of the Pathological Narcissism Inventory. Psychological Assessment, 21(3), 365-379

Rumble, A. C., Van Lange, P. A. M., \& Parks, C. D. (2010). The benefits of empathy: When empathy may sustain cooperation in social dilemmas. European Journal of Social Psychology, 40(5), 856-866

Seniati, L. (2009). Path analysis dan structural equation model. Retrieved from http://staff.ui.ac.id/internal/131998622/material/PATHANALYSIS.pdf

Singer, N. (2009). Highlights of the 2009 behavior, energy, and climate change conference. Retrieved from http://www.apa.org/science/about/psa/2010/01/becc.aspx

Thompson, S. C. G., \& Barton, M. A. (1994). Ecocentric and anthropocentric attitudes toward the environment. Journal of Environmental Psychology, 14, 149-157.

Twenge, J. M., Campbell, W. K., \& Freeman, E. C. (2012). Generational differences in young adults' life goals, concern for others, and civic orientation, 1966-2009. Journal of Personality and Social Psychology, 102(5), 10451062. 